\title{
The Diversity of Strawberry latent ringspot virus in New Zealand
}

Joe Tang, Lisa I. Ward, and Gerard R. G. Clover, Plant Health and Environment Laboratory, Ministry for Primary Industries, Auckland 1140 New Zealand

\begin{abstract}
Tang, J., Ward, L. I., and Clover, G. R. G. 2013. The diversity of Strawberry latent ringspot virus in New Zealand. Plant Dis. 97:662-667.

Strawberry latent ringspot virus (SLRSV) is widespread in many countries, especially in Europe. The virus was thought to be uncommon in New Zealand, having only been recorded in Prunus spp. However, this study revealed that SLRSV infects a much wider range of hosts. From 1999 to 2009, SLRSV was isolated from anemone (Anemone $\times$ hybrida), blackberry (Rubus spp.), impatiens (Impatiens walleriana), pepino (Solanum muricatum), and tibouchina (Tibouchina sp.) in the North Island of New Zealand. These SLRSV isolates were identified using electron microscopy, mechanical inoculation, enzyme-linked immunosorbent assay, and reverse-transcription polymerase chain reaction techniques. This is thought to be the first report of anemone, impatiens, pepino, and tibouchina as hosts of SLRSV. Phylogenetic

analysis and host range suggest that the five newly identified New Zealand isolates belong to two distinct strains: blackberry and impatiens isolates represent one strain and the other three isolates, plus the flowering cherry isolate reported previously in New Zealand, represent another strain. Both these strains are distinct from isolates reported elsewhere in the world. The strain infecting blackberry and impatiens is especially different and produced an unusual reaction in mechanical inoculation tests on herbaceous indicators. It is postulated that SLRSV may have gone undetected on its wider host range in New Zealand due to the latent infection in some hosts. The relationship of SLRSV isolates between New Zealand and overseas and the transmission modes of this virus are also discussed.
\end{abstract}

Strawberry latent ringspot virus (SLRSV) was first identified from strawberry and raspberry in Scotland in 1964 by Lister (15). This virus is transmitted by the soil-inhabiting nematodes Xiphinema coxi and $X$. diversicaudatum $(15,22)$ and, for this reason, the virus was originally classified as a nepovirus. In 2005, SLRSV was moved to the genus Sadwavirus (19). More recently, phylogenetic analysis revealed that SLRSV shares characteristics with members of the genera Cheravirus, Fabavirus, Comovirus, and Sadwavirus which are indicative of the uniqueness of SLRSV (26) and, therefore, it was moved out of Sadwavirus and classified as a tentative member in the newly formed family Secoviridae (27).

SLRSV infects a broad range of hosts, including many economically important crops such as small fruit (strawberry, raspberry, blackberry, blackcurrant, and redcurrant), stone fruit (cherry, peach, and plum), vegetables (celery, asparagus, and parsley), ornamentals (lily, narcissus, and rose), grapevine, and olive (1,36,13-17,22,28). The virus also infects tree species (e.g. Aesculus, Euonymus, and Robinia spp.; 25). SLRSV is generally considered a European virus although it has been reported in Australia, Canada, India, Lebanon, Turkey, the United States, North Africa (e.g., Egypt and Tunisia), and New Zealand (7-9,14,17, 30). In New Zealand, SLRSV was thought to be uncommon, because it had previously been reported with a very low incidence only in Prunus spp. $(10,12,24)$. More recently, however, SLRSV has been found to infect a much wider range of hosts than previously thought.

Despite its wide distribution, SLRSV (or particular strains of SLRSV) is still considered to be a regulated pest in many countries. In New Zealand, the SLRSV strains infecting strawberry and grape are regulated. From a biosecurity perspective, it was consid-

Corresponding author: J. Tang, E-mail: joe.tang@mpi.govt.nz

* The $\boldsymbol{e}$-Xtra logo stands for "electronic extra" and indicates that Figures 1 and 3 appear in color in the online edition.

Accepted for publication 4 December 2012.

http://dx.doi.org/10.1094/PDIS-07-12-0703-RE

(c) 2013 The American Phytopathological Society ered important to establish which strains of this virus are present in New Zealand and their relationship to SLRSV strains that have been reported from overseas.

\section{Materials and Methods}

Plant material. Plant leaves showing suspect viral symptoms (Fig. 1) were collected by orchard producers, researchers, or domestic garden owners and sent to the Plant Health and Environment Laboratory to identify the causal viruses. The original diseased samples in this study were collected from different locations on the North Island, New Zealand, as listed in Table 1.

Transmission electron microscopy and immunosorbent electron microscopy. A modified crude leaf sap preparation (21) and immunosorbent electron microscopy (ISEM) (18) were used to examine SLRSV particles for original hosts or selected symptomatic herbaceous indicator plants. Approximately $0.5 \mathrm{~g}$ of each sample was homogenized in $2.5 \mathrm{ml}$ of $0.1 \mathrm{M}$ potassium phosphate buffer ( $\mathrm{pH}$ 7.4). For direct transmission electron microscopy (TEM), $10 \mu \mathrm{l}$ of this crude sap was placed on a 400-mesh carbonfilm copper grid (ProSciTech). For ISEM, the grid was coated with SLRSV antibody (Loewe Biochemica $\mathrm{GmbH}$ ) in a 1:50 dilution for $30 \mathrm{~min}$ and washed before the leaf sap was placed. The grid was gently washed with 30 drops of distilled water, then stained with 8 to 10 drops of $1 \%$ uranyl acetate. Grids were examined using a JEOL JEM-1230 transmission electron microscope (JEOL Ltd.).

Mechanical transmission. Virus-infected samples were inoculated on to a series of eight herbaceous indicator species (Chenopodium amaranticolor, C. quinoa, Cucumis sativus, Nicotiana benthamiana, N. clevelandii, N. occidentalis '37B', N. sylvestris, and N. tabacum 'White Burley'). At least four plants of each species were used to ensure the reliability of the inoculations. Approximately $1 \mathrm{~g}$ of symptomatic leaf tissue was ground thoroughly in a mortar or extraction bag with $4 \mathrm{ml}$ of $0.1 \mathrm{M}$ phosphate buffer, $\mathrm{pH}$ 7.4, containing 5\% PVP-40 (wt/vol) and $0.12 \% \mathrm{Na}_{2} \mathrm{SO}_{3}(\mathrm{wt} / \mathrm{vol})$. Indicator plants were maintained in darkness for 16 to $24 \mathrm{~h}$ before inoculation and dusted with number 400 carborundum as an abrasive prior to inoculation. Four to six leaves were inoculated per plant, and the inoculated leaves were briefly rinsed with cold water after inoculation. The indicator plants were maintained in a glasshouse at a mean temperature of $18^{\circ} \mathrm{C}$ and monitored for symptom development over a 6-week period. 
Enzyme-linked immunosorbent assay. Double-antibody sandwich (DAS) enzyme-linked immunosorbent assay (ELISA) was performed on selected symptomatic herbaceous indicator plants using commercial polyclonal antiserum raised against SLRSV (Loewe Biochemica $\mathrm{GmbH}$ ), according to the manufacturer's instructions. Healthy leaves of each species were used as negative controls. Absorbance was measured at $405 \mathrm{~nm}$ on a Bio-Rad M680 microplate spectrophotometer (Bio-Rad Laboratories Inc.). A sample was interpreted as positive when the absorbance value was more than three times the value of the negative control.

RNA extraction. Total RNA was extracted from fresh leaf tissue with two different methods, according to the manufacturer's instructions: RNeasy Plant Mini Kit (Qiagen) and Thermo Kingfisher $\mathrm{mL}$ semi-automated nucleic acid extraction machine (Thermo Scientific) in conjunction with an InviMag Plant $\mathrm{Kit} / \mathrm{KFmL}$ (Invitek $\mathrm{GmbH}$ ). RNA was eluted in nuclease-free water or elution buffer and stored at $-80^{\circ} \mathrm{C}$ prior to use. The quality of RNA extraction with these two methods was compared by measurement of RNA concentration and quality; no significant difference was observed between these methods (data not shown). An internal-control polymerase chain reaction (PCR) was done for all RNA extracts using nad5-s and nad5-as primers (20) to ensure the PCR competency of the RNA extracts (data not shown).

Reverse transcription polymerase chain reaction and sequencing. Reverse-transcription (RT)-PCR was performed using either a two-step or one-step protocol. For two-step RT-PCR, complementary DNA (cDNA) was synthesized using Superscript III reverse transcriptase (Invitrogen ) in a final volume of $20 \mu$ l. Total viral RNA $(4 \mu \mathrm{l})$ was mixed with $4 \mu \mathrm{l}$ of $5 \times$ RT buffer, $0.2 \mu \mathrm{l}$ of 40 $\mathrm{U} / \mu \mathrm{l}$ RNasin Plus (Promega Corp.), $0.5 \mu \mathrm{l}$ of $0.5 \mu \mathrm{g} / \mu \mathrm{l}$ random hexamer primers, $2 \mu \mathrm{l}$ of a $10 \mathrm{mg} / \mathrm{ml}$ bovine serum albumin (BSA) solution, and nuclease-free (diethylpyrocarbonate-treated) water to give a reaction volume of $16 \mu \mathrm{l}$. This solution was heated for 10 min at $70^{\circ} \mathrm{C}$ and immediately placed on ice for $1 \mathrm{~min}$, then incubated with $0.5 \mu \mathrm{l}$ each of water and $200 \mathrm{U} / \mu \mathrm{l}$ Superscript III reverse transcriptase, $2 \mu \mathrm{l}$ of dithiothreitol, and $1 \mu \mathrm{l}$ of $10 \mathrm{mM}$
dNTPs for $1 \mathrm{~h}$ at $50^{\circ} \mathrm{C}$. The PCR reaction was performed with GoTaq Green Master Mix (Promega Corp.), using $2 \mu \mathrm{l}$ of cDNA template, $10 \mu \mathrm{l}$ of $2 \times$ GoTaq master mix, $1 \mu \mathrm{l}$ each of $5 \mu \mathrm{M}$ forward and reverse primers, and $6 \mu \mathrm{l}$ of nuclease free water, making a total volume of $20 \mu \mathrm{l}$. The one-step RT-PCR was performed with the SuperScript III one-step RT-PCR system with Platinum Taq polymerase (Invitrogen) using $2 \mu \mathrm{l}$ of RNA template, $1 \mu \mathrm{l}$ each of $5 \mu \mathrm{M}$ forward and reverse primers, $1 \mu \mathrm{l}$ of a $10 \mathrm{mg} / \mathrm{ml}$ BSA solution, $0.8 \mu \mathrm{l}$ of SSIII RT/Platinum Taq mix, and $0.2 \mu \mathrm{l}$ of RNasin Plus, and made up to a final volume of $20 \mu \mathrm{l}$ with nuclease-free water. RT-PCR was performed on a GeneAmp PCR system 9700 (Applied Biosystems). Based on an analysis of all the SLRSV sequences in GenBank, a pair of published primers, SLRSV-F 5'-CCTCTCCAACCTGCT AGACT-3' and SLRSV-R 5'AAGCGCATGAAGGTGTAACT-3' (23), was selected to screen for SLRSV initially. In order to further characterize the obtained SLRSV isolates, an additional reverse primer, SLRSV-2R 5'CTCCTTGAGAAATGCCTAAG-3' (anneals to untranslated region of RNA2, nucleotide positions 3,307 to 3,326) was designed and paired with SLRSV-F to amplify a 2,176-bp fragment which spans both the large and small coat protein $(\mathrm{CP})$ region. Thermocycling conditions were $94^{\circ} \mathrm{C}$ for $5 \mathrm{~min}$; then, 40 cycles of $94^{\circ} \mathrm{C}$ for $30 \mathrm{~s}, 52^{\circ} \mathrm{C}$ for $30 \mathrm{~s}$, and $68^{\circ} \mathrm{C}$ for $2 \mathrm{~min}$; followed by a final extension at $68^{\circ} \mathrm{C}$ for $10 \mathrm{~min}$. All PCR products of the correct size were purified using MicroSpin S300 HR Columns (GE Healthcare) and ligated into the pCR4-TOPO TA cloning vector system (Invitrogen). At minimum, two clones of each product were sequenced twice using vector-specific primers on an ABI 3130xl genetic analyzer (Applied Biosystems) by Ecogene, Auckland, New Zealand. Additional primers (not shown) were designed for internal priming where necessary. Sequence assembling and phylogenetic analysis were conducted using Geneious 5.0.4 software (Biomatters Ltd.). The obtained sequences were annotated and submitted to the National Center for Biotechnology Information database under accessions HM591195 to HM591198.

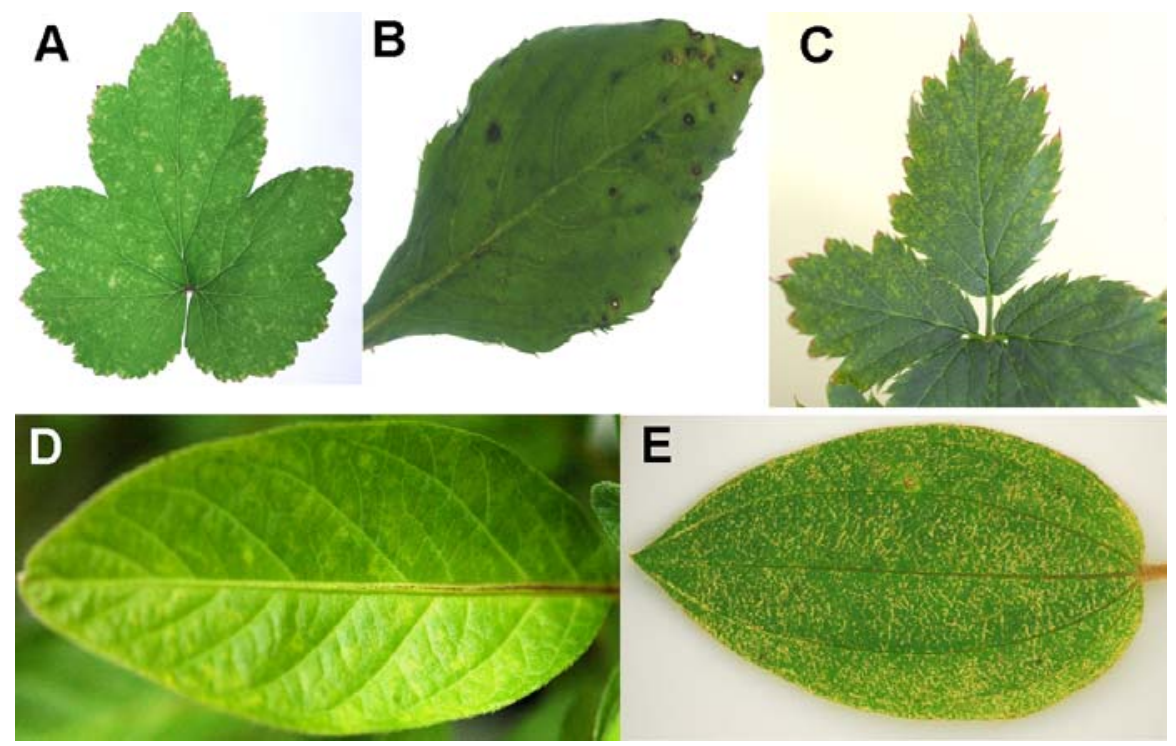

Fig. 1. Foliar symptoms on plants naturally infected with Strawberry latent ringspot virus (SLRSV). A, Chlorotic spots on Anemone $\times$ hybrida. B, Chlorotic streaks and necrotic rings on Impatiens walleriana. C, Chlorotic spotting on Rubus spp. D, Chlorotic mottle on Solanum muricatum. E, Vein chlorosis on Tibouchina sp.

Table 1. Source of Strawberry latent ringspot virus-infected samples

\begin{tabular}{llll}
\hline Species (family) & \multicolumn{1}{c}{ Symptom } & Type of property, location & Year collected \\
\hline Anemone $\times$ hybrida (Ranunculaceae) & Chlorotic spots & Domestic garden, Auckland & 1999 \\
Impatiens walleriana (Balsaminaceae) & Chlorotic streaks and necrotic rings & Domestic garden, Auckland & 2009 \\
Rubus spp. (Rosaceae) & Chlorotic spotting & Fruit orchard, Kapiti Coast & 2005 \\
Solanum muricatum (Solanaceae) & Chlorotic mottle & Research institute, Auckland & 2005 \\
Tibouchina sp. (Melastomataceae) & Vein chlorosis & School campus, Auckland & 2003 \\
\hline
\end{tabular}




\section{Results}

TEM and ISEM. The crude sap preparation from symptomatic Chenopodium amaranticolor and $C$. quinoa plants revealed the presence of isometric virus particles approximately $30 \mathrm{~nm}$ in diameter. Along with individual particles, many tubular structures containing virions were observed (Fig. 2A). The tubular structure has previously been observed to occur commonly in plants infected with SLRSV and with some other viruses, especially nepoviruses (e.g. Cherry leaf roll virus and Tobacco ringspot virus) $(2,29,31)$. Numerous isometric particles were trapped by SLRSV-specific antibodies when using ISEM (Fig. 2B). Particles and tubules containing virions were not observed in the original hosts.

Mechanical transmission. Virus-like symptoms were observed on plants of $C$. amaranticolor, $C$. quinoa, and Cucumis sativus when inoculated with sap from diseased anemone, blackberry, impatiens, pepino, and tibouchina. The inoculated Chenopodium amaranticolor and C. quinoa exhibited local necrotic spots followed by systemic leaf distortion, plant dwarfing ( $C$. amaranticolor), or tip necrosis (C. quinoa), while Cucumis sativus developed systemic leaf mosaic (Fig. 3A-C). The symptoms on Chenopodium quinoa became less severe and Cucumis sativus eventually recovered 2 to 3 weeks after the initial symptoms were observed. The observed symptoms and symptom development on these herbaceous species were similar to those reportedly induced by SLRSV $(2,10,22)$. Moreover, local or systemic necrotic lesions

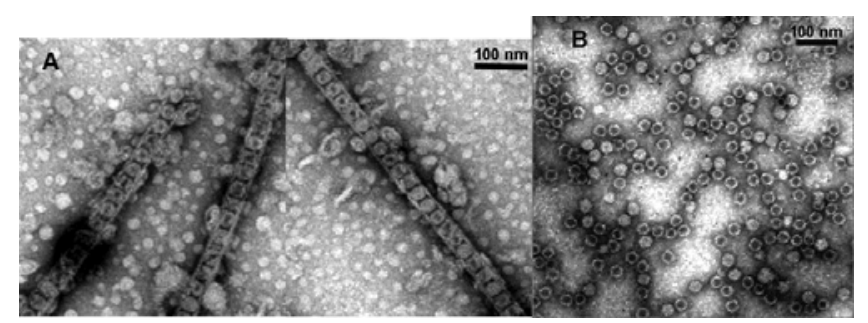

Fig. 2. Strawberry latent ringspot virus (SLRSV) particles from Chenopodium amaranticolor inoculated from infected Rubus spp. A, Linear tubules containing virions from a crude sap preparation. B, Isometric particles captured by SLRSV antiserum (Loewe) using immunosorbent electron microscopy. were observed on $N$. benthamiana, $N$. clevelandii, and $N$. occidentalis inoculated with sap from the diseased blackberry and impatiens; the former also induced systemic chlorotic rings on N. tabacum (Fig. 3D-G). The systemic symptoms on these Nicotiana spp. became less severe or invisible about 3 weeks after the initial symptoms were observed. Symptom observation results for inoculated indicator plants are summarized in Table 2.

DAS-ELISA. Leaf samples of the symptomatic Chenopodium amaranticolor, C. quinoa, and Cucumis sativus plants were tested for the presence of SLRSV using ELISA. These herbaceous species inoculated from samples listed in Table 1 tested positive for SLRSV. No reactions were observed for healthy controls of each species.

RT-PCR and sequence analysis. RNA extractions from the original host species and all the inoculated herbaceous plants were tested for SLRSV by RT-PCR, using primers SLRSV-F and SLRSV-R. Amplicons of the correct size were obtained from all five original samples, as well as all symptomatic herbaceous species and some asymptomatic species (Table 2). Direct sequencing of the amplicons confirmed these to be SLRSV. Amplicons of 2,176 bp were obtained using the SLRSV-2R and SLRSV-F primer pair for each isolate from symptomatic Chenopodium quinoa. These amplicons were cloned and sequenced as described, and the consensus sequence obtained was deposited in GenBank (accession numbers HM591195 to HM591198).

Phylogenetic analysis was conducted to compare sequences across the region of the large and small CPs $(1,869 \mathrm{bp})$ of RNA2 from New Zealand SLRSV isolates with SLRSV sequences from overseas. A pairwise comparison of the 1,869-bp nucleotide sequence revealed that the New Zealand isolates from anemone, pepino, tibouchina, and flowering cherry (GenBank accession number X75165) (11) share over 98\% identity with each other but only 85.4 to $85.8 \%$ identity with the New Zealand blackberry and impatiens isolates; the latter two isolates share $99.6 \%$ identity to each other. All New Zealand isolates have less than $80 \%$ nucleotide identity to a golden ginger mint (Mentha $\times$ gracilis, 'Variegata') isolate from the United States (GenBank accession number AY860979) and a strawberry (Fragaria vesca) isolate from the United Kingdom (type isolate, GenBank accession number X77466). For amino acid sequences, all New Zealand isolates

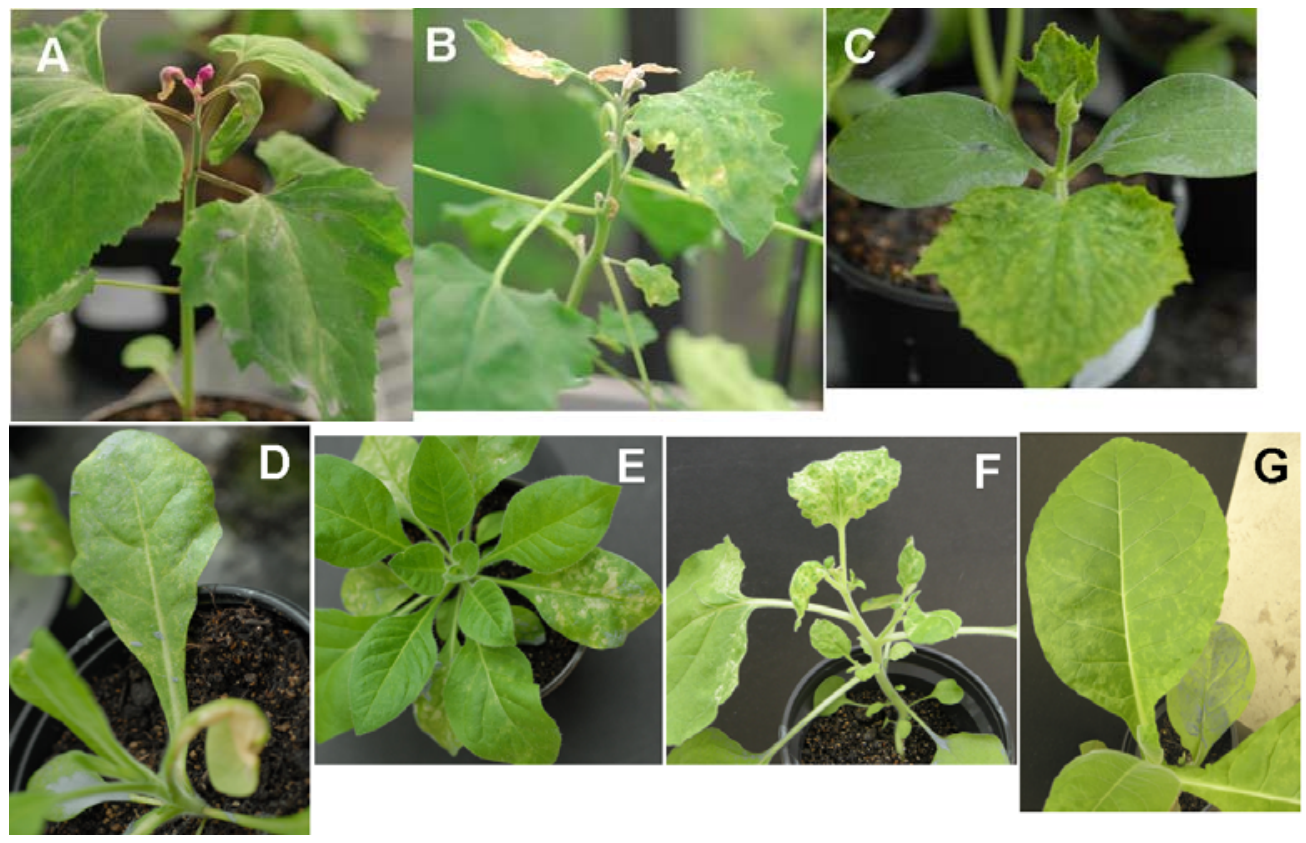

Fig. 3. Foliar symptoms observed on herbaceous indicator plants inoculated with Strawberry latent ringspot virus (SLRSV) from infected Rubus spp. induced A, leaf deformation and plant dwarf on Chenopodium amaranticolor, B, tip necrosis on C. quinoa; and C, leaf mosaic on Cucumis sativus. SLRSV-infected Anemone $\times$ hybrida, Impatiens walleriana, Solanum muricatum, and Tibouchina sp. induced similar symptoms on these three species. The Rubus spp. also induced local and systemic necrotic lesions on D, Nicotiana occidentalis and E, N. clevelandii, and chlorotic or necrotic rings on F, N. benthamiana and G, N. tabacum. SLRSV-infected I. walleriana induced similar symptoms on these Nicotiana spp., except $N$. tabacum, which was symptomless. 
share over $96 \%$ identity to each other and approximately $93 \%$ to the U.S. isolate and $90 \%$ to the U.K. isolate. A phylogenetic tree (Fig. 4) constructed from the complete $\mathrm{CP}$ nucleotide sequence indicates that the New Zealand isolates are divided into two groups and that both groups are distinct from the U.K. and U.S. isolates.

Along with the complete $\mathrm{CP}$ sequence, GenBank contains a few short fragments $(<500 \mathrm{bp})$ of SLRSV sequence from the same region; this includes four sequences from mint from the United States (HQ456535, HQ456536, HQ456537, and AY438666), three sequences from black locust (Robinia pseudoacacia) from Poland (DQ324374, DQ324375, and DQ324376), and one sequence from strawberry from Canada (AY461735). The New Zealand SLRSV isolates share between 78.1 and $85.7 \%$ nucleotide identity with these overseas isolates.

\section{Discussion}

SLRSV was first identified in New Zealand in 1973 from a single sweet cherry tree (Prunus avium 'Bing') (12) and, for some time, was thought to be rare in this country. During a survey of flowering cherry ( $P$. serrulata Lindl. sensu lato) in 1994, SLRSV was detected from three flowering cherry trees in the Auckland region but the virus was not detected in 390 trees from other districts (10). This virus was found again in a single Japanese plum tree ( $P$. salicina) out of 485 trees sampled during a stonefruit crop survey in 1998 (24). However, since 1998, SLRSV has been de- tected in a much wider range of hosts, including anemone, blackberry, impatiens, pepino, and tibouchina. Anemone, impatiens, pepino, and tibouchina are all new host records for SLRSV in the world. The SLRSV-infected hosts belong to different plant families, including Ranunculaceae, Rosaceae, Balsaminaceae, Solanaceae, and Melastomataceae. The detections of SLRSV in the families Balsaminaceae (Impatiens walleriana) and Melastomataceae (Tibouchina sp.) are thought to be the first records of this virus naturally infecting species within these families.

SLRSV is known to induce severe symptoms on strawberry, celery, rose, and black locust (22). However, SLRSV has not been found on these hosts in New Zealand. From the previous records of SLRSV on Prunus spp. in New Zealand, no obvious symptoms were found on flowering cherry (10) or Japanese plum (24); although five sweet cherry trees showed severe rasp leaf symptoms, only one of these tested positive for SLRSV. As such, the rasp leaf symptoms may not be associated with SLRSV infection (12). In this study, the symptomatic pepino plant was found to be coinfected with Potato virus $M$ (PVM). PVM has not previously been reported in pepino and it is not known whether the observed symptoms were induced by PVM, SLRSV, or both. The necrotic ringspot symptoms on the SLRSV-infected impatiens plant may be caused by another virus-for example, Impatiens necrotic spot virus, Tomato spotted wilt virus, or Tobacco ringspot virus (TRSV)—or pathogen, or even by environmental stress. Tospo-

Table 2. Experimental host range for different isolates of Strawberry latent ringspot virus (SLRSV) determined by mechanical inoculation and reversetranscription polymerase chain reaction (RT-PCR) ${ }^{\mathrm{a}}$

\begin{tabular}{|c|c|c|c|c|c|c|c|c|c|c|}
\hline \multirow[b]{2}{*}{ Indicator plant } & \multicolumn{2}{|c|}{ Anemone } & \multicolumn{2}{|c|}{ Impatiens } & \multicolumn{2}{|c|}{ Rubus } & \multicolumn{2}{|c|}{ Solanum } & \multicolumn{2}{|c|}{ Tibouchina } \\
\hline & Sym. & PCR & Sym. & PCR & Sym. & PCR & Sym. & PCR & Sym. & PCR \\
\hline Chenopodium amaranticolor & $\mathrm{s}$ & + & $\mathrm{s}$ & + & s & + & $\mathrm{s}$ & + & s & + \\
\hline C. quinoa & $\mathrm{s}$ & + & $\mathrm{s}$ & + & s & + & s & + & $\mathrm{s}$ & + \\
\hline Cucumis sativus & $\mathrm{s}$ & + & $\mathrm{s}$ & + & $\mathrm{s}$ & + & s & + & $\mathrm{s}$ & + \\
\hline Nicotiana benthamiana & ns & - & $\mathrm{s}$ & + & $\mathrm{s}$ & + & ns & - & ns & + \\
\hline N. clevelandii & ns & + & $\mathrm{s}$ & + & s & + & ns & + & ns & - \\
\hline N. occidentalis & ns & - & $\mathrm{s}$ & + & s & + & ns & - & ns & - \\
\hline N. sylvestris & ns & + & ns & + & ns & + & ns & + & ns & + \\
\hline N. tabacum & ns & - & ns & + & $\mathrm{s}$ & + & ns & - & ns & - \\
\hline
\end{tabular}

${ }^{a}$ Sym., symptom observation for inoculated indicator plants (S, symptomatic or ns, no symptoms) and PCR, results of RT-PCR for SLRSV (+, positive or - , negative).

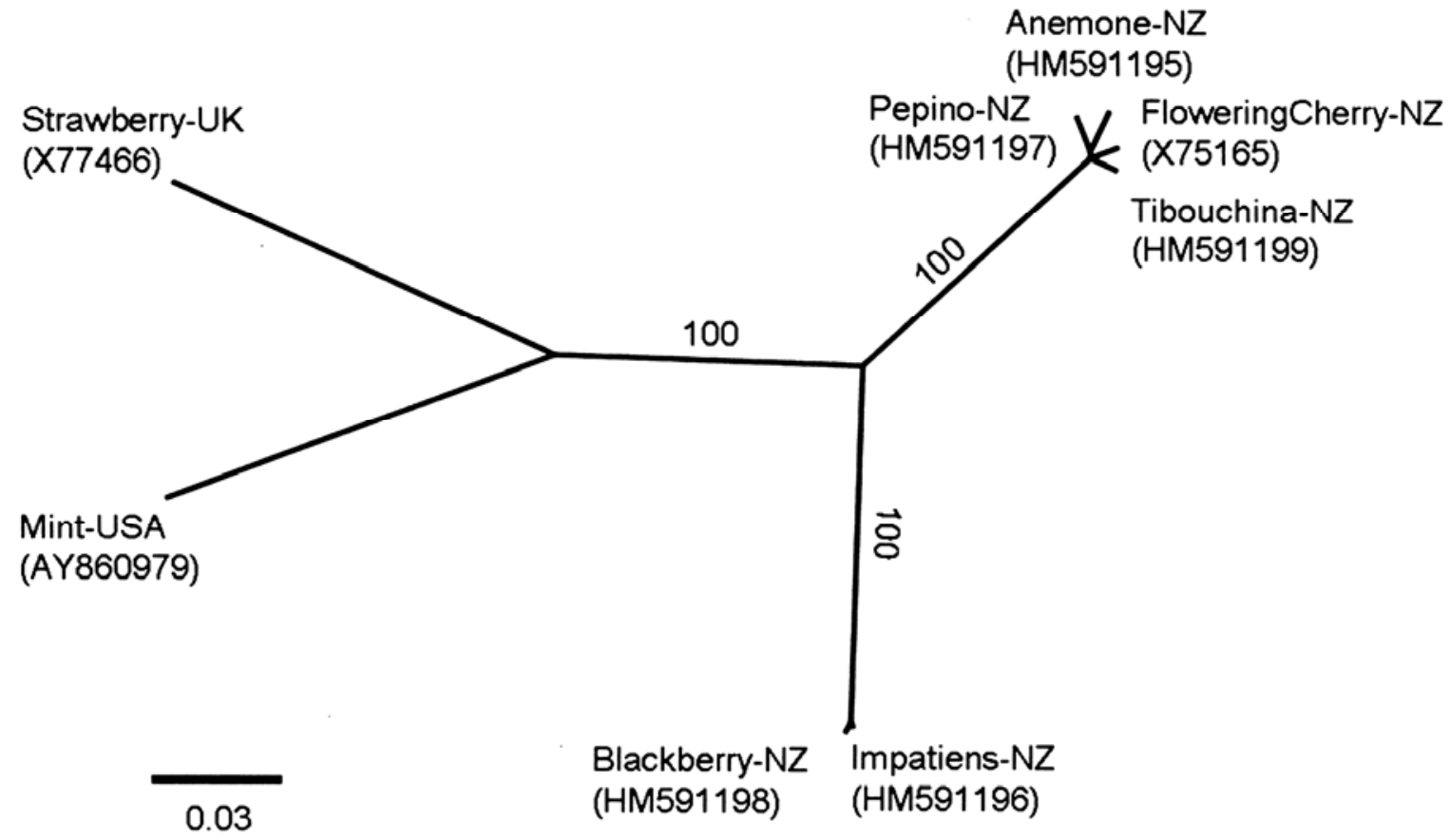

Fig. 4. Phylogenetic relationship of Strawberry latent ringspot virus based on nucleotide sequence (1,869 bp) from the large and small coat proteins. GenBank accession numbers are in brackets. Numbers at each branch point indicate bootstrap values. 
viruses and TRSV were ruled out by RT-PCR, and a reverse inoculation from SLRSV-infected $C$. quinoa to healthy impatiens plants resulted in a symptomless infection. The possibility of latent infections may explain why SLRSV has gone undetected in a wider host range in New Zealand.

For the five New Zealand SLRSV isolates in this study, the symptoms observed on indicator hosts $C$. amaranticolor, C. quinoa, and Cucumis sativus were similar to those reported earlier, as were the latent infections on some Nicotiana spp. $(2,10,25)$. However, isolates from blackberry and impatiens induced obvious symptoms on $N$. benthamiana, N. clevelandii, and N. occidentalis while the former also induced symptoms on N. tabacum. These two isolates were also found to be easier to transmit onto indicator plants and induced symptoms quicker than other isolates. Some nepoviruses (e.g., Arabis mosaic virus, Cherry leaf roll virus, Raspberry ringspot virus, TRSV, Tomato black ring virus, and Tomato ringspot virus) may induce similar symptoms on these herbaceous species. However, the presence of these viruses was ruled out by testing the indicator plants using ELISA or PCR. Other viruses, present in New Zealand and previously reported to infect Rubus spp.-for example, Black raspberry necrosis virus (an unassigned species of Secoviridae) and Raspberry bushy dwarf virus (Idaeovirus) - also tested negative by RT-PCR, as did two viruses not present in New Zealand, Cherry rasp leaf virus (Cheravirus) and Blackberry chlorotic ringspot virus (Ilarvirus). Therefore, it is thought that the observed symptoms on Nicotiana spp. were likely to be caused by a novel strain of SLRSV.

Phylogenetic analysis revealed that the New Zealand isolates represent two distinct strains, suggesting that SLRSV may have been introduced inadvertently into New Zealand, possibly via importation of symptomless plant material, on at least two separate occasions. The blackberry and impatiens isolates are almost identical in the $\mathrm{CP}$ regions and are considered to be the same strain; however, these isolates only share 85.4 to $85.8 \%$ nucleotide identity with other New Zealand isolates (anemone, flowering cherry, pepino, and tibouchina), which make up the second strain. The presence of two different strains is also supported by the different reactions observed on herbaceous plants when inoculated with the blackberry and impatiens isolates. Although SLRSV has been reported to naturally infect various plant species, the availability of sequence data in GenBank is limited. There are only 22 sequences in GenBank, of which 16 sequences are in the polyprotein region (includes the large and small CP) of RNA2. Eight of these sequences (six from New Zealand and one each from the United Kingdom and United States) cover the complete large and small $\mathrm{CP}$, and the remaining are short pieces of sequence $(<500 \mathrm{bp})$. Phylogenetic analysis also revealed a great diversity of nucleotide sequences among the available SLRSV isolates; the New Zealand isolates are distinct from all other isolates elsewhere in the world, because they share less than $80 \%$ identity with either U.K. or U.S. isolates in the complete CP region (1,869 bp) and 78.1 to $85.7 \%$ identity with other SLRSV isolates with a shorter length $(<500 \mathrm{bp})$. The relationship between isolates from New Zealand and those from overseas is not totally clear due to the lack of sequence data in GenBank. However, the results would support New Zealand's measures to prevent the entry of new strains into New Zealand.

One of the nematode vectors of SLRSV, $X$. diversicaudatum, occurs in New Zealand. However, the nematode was not found in soil samples collected from under the SLRSV-infected flowering cherry trees in 1994 (10). During the stonefruit crop survey in $1998, X$. diversicaudatum was found to occur in $10 \%$ of soil samples collected from the various sites surveyed; however, SLRSV was found at only one of these sites, and the nematode was not detected in soil collected from beneath this infected tree (24). In 2003, X. diversicaudatum was not detected in soil collected from under the tibouchina tree found to be infected with SLRSV. Furthermore, in 2005, 17 of 25 blackberry plants collected from an orchard tested positive for SLRSV. However, the vector nematode was found in only two of five soil samples collected from under SLRSV-infected plants. These results indicate that there is not a strong correlation between the presence of SLRSV and the presence of $X$. diversicaudatum in New Zealand. Similarly, in the United States, SLRSV was found in commercial strawberry fields where the nematode vectors are not known to exist and in mint nurseries where the soil was treated with methyl bromide to eliminate nematode vectors (26). It had been thought that SLRSV may be transmitted by an insect vector in addition to nematodes but transmission studies using the mint aphid and the spotted cucumber beetle failed to demonstrate transmission of SLRSV by either vector (26). Everett et al. (10) also suggested the possibility of spread of SLRSV on flowering cherries by pollen transmission. An alternative mode of spread, particularly in commercial nurseries or orchards, may be due to cultivation practices (e.g., propagation by cutting or grafting using infected materials and tools).

\section{Literature Cited}

1. Belli, G., Fortusini, A., and Vegetti, G. 1980. Properties of a strain of strawberry latent ringspot virus, associated with a rosetting disease of peach in northern Italy. Acta Phytopathol. Acad. Sci. Hung. 15:113-117.

2. Borodynko, N., Hasiow, B., Figlerowicz, M., and Pospieszny, H. 2007. Identification of the new strain of Strawberry latent ringspot virus isolated from black locust (Robinia pseudoacacia L.). J. Phytopathol. 155:738-742.

3. Brunt, A. A. 1966. The occurrence of cucumber mosaic virus and four nematode-transmitted viruses in British narcissus crops. Plant Pathol. 15:157160.

4. Cohen, J., Gera, A., and Loebenstein, G. 1995. Strawberry latent ringspot virus in lilies. Eur. J. Plant Pathol. 101:217-219.

5. Cooper, P. 1981. Strawberry latent ringspot virus in parsnips. Plant Pathol. 30:59-60.

6. Credi, R., Babini, A. R., Betti, L., Bertaccini, A., and Gelli, C. 1981. A distinctive isolate of Strawberry latent ringspot virus from grapevines in Italy. Phytopathol. Mediterr. 20:56-63.

7. Distribution Maps of Plant Diseases. 2003. Strawberry latent ringspot virus April (Edition 1). CABI, Map 891. http://www.cabi.org/dmpd/?load module $=$ review \&page $=4050 \&$ reviewid $=16275 \&$ site $=165$

8. El-Air, M., Mahfoudi, N., Digiaro, M., Najjar, A., and Elbeaino, T. 2011 Detection of olive-infecting viruses in Tunisia. J. Phytopathol. 159:283-286.

9. Elbeaino, T., Choueiri, E., Jreijiri, F., and Digiaro, M. 2007. First report of Strawberry latent ringspot virus in Lebanese cherry orchards. J. Plant Pathol. (Suppl. 3) 89:S74.

10. Everett, K. R., Milne, K. S., and Forster, R. L. S. 1994. A new host record: Strawberry latent ringspot virus isolated from flowering cherry. Australas. Plant Pathol. 23:11-15.

11. Everett, K. R., Milne, K. S., and Forster, R. L. S. 1994. Nucleotide sequence of the coat protein genes of Strawberry latent ringspot virus: lack of homology to the nepoviruses and comoviruses. J. Gen. Virol. 75:1821-1825.

12. Fry, P. R., and Wood, G. A. 1973. Further viruses of Prunus in New Zealand. N.Z. J. Agric. Res. 16:131-142.

13. Hanson, C. M., and Campbell, R. N. 1979. Plant Dis. Rep. 63:142-146.

14. Kulshrestha, S., Hallan, V., Raikhy, G., Ram, R., and Zaidi, A. A. 2004 Strawberry latent ringspot virus infecting roses in India. Plant Dis. 88:86.

15. Lister, R. M., 1964. Strawberry latent ringspot: A new nematode-borne virus. Ann. Appl. Biol. 54:167-176.

16. Marte, M., Gadani, F., Savino, V., and Rugini, E. 1986. Strawberry latent ringspot virus associated with a new disease of olive in Central Italy. Plant Dis. 70:171-172.

17. Martin, R. R. Tzanetakis, I. E. Barnes, J. E., and Elmhirst, J. F. 2004. First report of Strawberry latent ringspot virus in strawberry in the United States and Canada. Plant Dis. 88:575.

18. Matthews, R. E. F., ed. 1993. Pages 235-236 in: Diagnosis of Plant Virus Diseases. CRC Press Inc., Boca Raton, FL.

19. Mayo, M. A. 2005. Changes to virus taxonomy 2004. Arch. Virol. 150:189198.

20. Menzel, W., Jelkmann, W., and Maiss, E. 2002. Detection of four apple viruses by multiplex RT-PCR assays with coamplification of plant mRNA as internal control. J. Virol. Methods 99:81-92.

21. Milne, R. G., Djelouah, K., Garcia, M. L., Dal Bo, E., and Grau, O. 1996. Structure of citrus ringspot psorosis associated virus particles: implications for diagnosis and taxonomy. Pages 189-197 in: Proc. 13th Conf. Int. Organ. Citrus Virol. (IOCV), Fuzhou, China.

22. Murant, A. F. 1974. Strawberry latent ringspot virus. No. 126 in: Description of Plant Viruses, CMI/AAB, Surrey, UK.

23. Postman, J. D., Tzanetakis, I. E., and Martin, R. R. 2004. First report of Strawberry latent ringspot virus in a Mentha sp. from North America. Plant Dis. 88:907.

24. Richmond, J. E., Cowley, J. M., Day, A., Hurrell, J. C., Page, G. D., Herrera, V. E., and Smales, T. E. 1998. Pest and disease survey of stonefruit crops in New Zealand (1997/98). Report to MAF Regulatory Authority. MAF Quality Management New Zealand Plant Protection Centre Auckland (internal report).

25. Schmelzer, K. 1969. Strawberry latent ringspot virus from Euonymus, 
Robinia and Aesculus. Phytopathol. Z. 66:1-24.

26. Tzanetakis, I. E., Postman, J. D., Gergerich, R. C., and Martin, R. R. 2006. A virus between families: nucleotide sequence and evolution of Strawberry latent ringspot virus. Virus Res. 121:199-204.

27. Virus Taxonomy-Ninth Report of the International Committee on Taxonomy of Viruses (2012). ICTV. Elsevier Academic Press, San Diego, CA.

28. Walkey, D. G. A., and Mitchell, J. 1969. Studies on a strap-leaf disease of celery caused by Strawberry latent ringspot virus. Plant Pathol. 18:167-172.
29. Walkey, D. G. A., and Webb, M. J. W. 1970. Tubular inclusion bodies in plants infected with viruses of the NEPO type. J. Gen. Virol. 7:159-166.

30. Youssef, S. A., Moawed, S. M., El-Sayed, M., and Shalaby, A. A. 2010 Detection of olive tree viruses in Egypt by one-step RT-PCR. Julius-KuhnArchiv. 427:51-55.

31. Zielin'ska, L., Pospieszny, H., and Borodynko, N. 2002. Electron microscopy of Strawberry latent ringspot virus (SLRSV) isolated from Robinia pseudoacacia. Phytopathol. Pol. 26:29-47. 